\title{
EFFECT OF AFFORESTATION OF AGRICULTURAL SOILS AND TREE SPECIES COMPOSITION ON SOIL PHYSICAL CHARACTERISTICS CHANGES
}

\author{
JAN VOPRAVIL ${ }^{1}$, VILÉM PODRÁZSKÝ²*, TOMÁŠ KHEL ${ }^{1}$, ONDŘEJ HOLUBÍK ${ }^{1}$, STA- \\ NISLAV VACEK ${ }^{2}$
}

${ }^{1}$ Research Institute for Soil and Water Conservation, Department of Soil Science and Soil Conservation, Žabovřeská 250, 15627 Prague 5 - Zbraslav, Czech Republic; e-mail: vopravil.jan@vumop.cz

${ }^{2}$ Czech University of Life Sciences Prague, Faculty of Forestry and Wood Sciences, Kamýcká 1176, 16521 Prague 6 - Suchdol, Czech Republic; e-mail: podrazsky@fld.czu.cz

* Author for correspondence

\begin{abstract}
Vopravil J., Podrázský V., Khel T., Holubík O., Vacek S.: Effect of afforestation of agricultural soils and tree species composition on soil physical characteristics changes. Ekológia (Bratislava), Vol. 33, No. 1, p. 67-80, 2014

This paper deals with the evaluation of the effect of afforestation of previously arable land to soil characteristics changes. One of the main aims was to evaluate the effects of each forest species on the soil structure quality after afforestation. Soil samples were taken at two climatically distinct subregions within the Czech Republic. Based on the different site conditions, two study sites were chosen at each locality for a total of four research sites. Detailed soil survey and basic forest stand inventories were conducted at all four sites. The first locality was established in the Rychnov nad Kněžnou district in the Protected Landscape Area of the Orlické mountains (soil type a Haplic Cambisol). The second locality was established in the Prague-East district (soil type a Haplic Cambisol and a Haplic Stagnosol). Afforestation had a positive influence on the soil physical characteristics which are important for the maintenance of soil stability. Forest cover has a major influence on increasing the soil porosity, by decreasing the reduced bulk density and increasing capillary and gravitational pores, which is crucial. Afforestation was also found to be positively related to increases in soil organic matter content in different forms, both stable and unstable, and tendency of considerable soil organic matter accumulation not only in the layer of surface humus but also in the entire soil profiles of the research sites. The main contributor to soil improvement after afforestation is the formation of stable soil aggregates. This is typical also for spruce and pine cover.
\end{abstract}

Key words: afforestation, former agricultural lands, soil, physical characteristics, Czech Republic.

\section{Introduction}

Forests occupy one-third of the world's land area and govern carbon transfer fluxes through photosynthesis and respiration, representing also an important carbon pool in particular ecosystem compartments (Brown, Lugo, 1990; Marková et al., 2011; Merganičová, Merganič, 
2010; Sefidi, Mohadjer, 2010). Maintenance or enhancement of soil organic matter (SOM) in forest ecosystems is crucial for sustainable use of forest resources because of the multiple effects of SOM on nutrient dynamics (Binkley, 1995), carbon cycle (Nambiar, 1996) and soil structure. Extensive roots of forest plants influence the microbial biomass in the soil by controlling carbon cycling between the atmosphere and the soil (Brown et al., 2002). Land use change has an important influence on soil properties and stabilization (Tisdall, Oades, 1982). With changes in land use, soil micro-aggregates may form macro-aggregates through the action of temporary and transient binding agents (Elliott, 1986). Soil structure, an important indicator of soil physical quality (Filho et al., 2002), is determined by the stability of soil aggregates. It directly or indirectly influences other physical and chemical properties of the soil and can be used as an indicator of soil degradation (Cerda, 2000). Forest soil dynamics improves soil aggregation while transferring organic carbon into deeper soil horizons (e.g., Podrázský et al., 2009). Kaiser et al. (2002) determined that forest subsoil has about $45 \%$ of total soil organic carbon (SOC) of the soil profile, and this fraction is bound to the clay particles forming $<20 \mu \mathrm{m}$ microaggregates. Afforestation results in significant sequestration of new carbon and stabilization of old carbon in physically protected SOM fractions, associated with microaggregates $(53-250 \mu \mathrm{m})$ and silt and clay $(<53 \mu \mathrm{m})$ (Del Galdo et al., 2003). The same authors showed that afforestation increases the SOC by $23 \%$ in the surface soil. The SOC sequestration depends on forest species and management (Del Galdo et al., 2003; Lal, 2002; Lamlom, Savidge, 2003; Blanco-Canqui, Lal, 2004). It is known that dominant tree species affect the availability and biochemical composition of organic matter inputs to soil (Leckie et al., 2004) and different root systems also affect aggregation differently, in relation to different root properties, exudates and functions (Chan, Heenan, 1998).

There is a trade-off between ecosystem carbon storage capacity and timber production. By selecting the appropriate tree species, it is possible to increase a soil's potential for carbon storage. Seely et al. (2002) estimated the long-term differences in SOC storage among forest ecosystems dominated by three tree species: white spruce (Picea glauca), trembling aspen (Populius tremuloides) and lodgepole pine (Pinus contorta var. latifolia), and found that all three were important carbon pools. They found total carbon storage to be the highest in aspen ecosystems, followed by pine and spruce. Vesterdal et al. (2002) found that soils growing Norway spruce (Picea abies L.) sequester $9 \mathrm{t}$ carbon $\mathrm{ha}^{-1}$ whereas those growing oak (Quercus robur L.) sequester only $2 \mathrm{t}$ carbon ha- ${ }^{-1}$ after 29 years and the SOC is mostly concentrated in the upper soil horizons.

Aggregate stability in the rhizosphere of Pinus halepensis is strongly correlated with the $\mathrm{C}$-biomass and soluble $\mathrm{C}$-fractions as well as with dehydrogenase and phosphatase activities. The combination of residue amendment and inoculation of P. halepensis with Pisolithus arhi$z u s$ significantly improves soil aggregate stability; this beneficial effect appearing to be mainly due to a reactivation of microbiological activity (Caravaca et al., 2001).

The mean weight diameter (MWD), defined as the sum of the weighted mean diameters of all size classes, characterize the structure of the soil (Six et al., 2000). In a study in northern Spain (Gartzia-Bengoetxea et al., 2009), these characteristics were found to be higher in semi-natural (beech and oak) stands than in cultivated mature pine. This result may be attributed to differences in annual organic matter inputs (Kavvadias et al., 2001), litter quality 
(Sariyildiz et al., 2005) and the enmeshing effect of roots and associated mycorrhizal hyphae, which may contribute to stabilization of topsoil aggregates.

It appears that macroaggregates $(0.25-2 \mathrm{~mm})$ may play an important role in aggregate dynamics in mature forests, independently of tree species (Gartzia-Bengoetxea et al., 2009).

The aim of this study is to determine the impact on soil properties and soil structure formation of afforestation by different forest species in the lower as well as higher-submountain elevations on marginal agricultural lands.

\section{Material and methods}

\section{Site descriptions}

Soil samples were taken at two climatically distinct subregions within the Czech Republic. Based on the different site conditions, two study sites were chosen at each locality for a total of four research sites. Detailed soil survey and basic forest stand inventories were conducted at all four sites.

The first locality (1) was established in the Rychnov nad Kněžnou district in the Protected Landscape Area of the Orlické mountains at an average altitude of $710 \mathrm{~m}$. Two research sites were chosen there: Lomy - Deštné (1a) and Pěčín - Neratov (1b).

1a) Lomy - Deštné site $\left[16^{\circ} 18^{\prime} 39-57^{\prime \prime} \mathrm{E} ; 50^{\circ} 17^{\prime} 8-13^{\prime \prime} \mathrm{N}\right]$ has a mildly warm and moist climate, with a mean annual precipitation of $707 \mathrm{~mm}$ and mean annual temperature of $7.3^{\circ} \mathrm{C}$. Geologically, the site is classified as orlickosněžnický crystalline complex with representation of metamorphic rocks of Paleozoic age (amphibolites, phyllites and schists). The soil type was a Haplic Cambisol (FAO, 2006, 2007).

Specification of Lomy - Deštné site vegetation:

a) Old Forest - selected stands afforested for very long time, with the age of forest cover being 120-165 years. The typological composition was defined by the overstory species European Beech (Fagus sylvatica) and Norway Spruce (Picea abies). Another species was Norway Maple (Acer platanoides). Soil samples were taken from a total of nine sites, representing three forest covers.

b) Forest - selected stands with longer period of afforested agricultural land with an overstory age of 18-57 years. The predominant species was Norway Spruce (Picea abies). Other species included European Beech (Fagus sylvatica), European larch (Larix decidua), Norway Maple (Acer platanoides), European Alder (Alnus glutinosa), European Ash (Fraxinus excelsior) and White Willow (Salix alba). Soil samples were taken from a total of 13 sites, representing 7 forest covers.

c) Afforestation - selected stands with very short period of afforestation since being used as agricultural land (first zone: 5-10 years, second zone: $20-40$ years). The overstory age was 7 years. The main species were European Beech (Fagus sylvatica) and Norway Spruce (Picea abies). Soil samples were taken from a total of two sites representing two forest covers.

d) Pasture - a reference site, selected close to the first afforested zone. Soil samples were taken from one site.

(1b) Pěčín - Neratov site $\left[16^{\circ} 25^{\prime} 53-56^{\prime \prime} \mathrm{E} ; 50^{\circ} 09^{\prime} 29-37^{\prime \prime} \mathrm{N}\right]$ has mildly warm and very moist climate. The mean annual temperature is $7{ }^{\circ} \mathrm{C}$ and mean annual precipitation is $848 \mathrm{~mm}$. Geological bedrock is metamorphic in origin and consists of paragneiss and phyllites. Soil samples were taken and the soil type was identified as a Haplic Cambisol (FAO 2006, 2007).

Specification of Pěčín - Neratov site vegetation:

a) Old Forest - selected stands afforested for very long time, with the age of forest cover being 93-141 years. The typological composition was defined by the principal overstory species: Norway Spruce (Picea abies). Other species included European Beech (Fagus sylvatica) and European silver fir (Abies alba). Soil samples were taken from a total of five sites, representing three forest covers.

b) Forest - selected stands with longer period of afforestation, with the age of forest cover being 41-57 years. 
The principal overstory species were Norway Spruce (Picea abies) and European Beech (Fagus sylvatica). Other overstory species included European Larch (Larix decidua), European Alder (Alnus glutinosa), Silver Birch (Betula pendula), Sycamore (Acer pseudoplatanus) and European Ash (Fraxinus excelsior). Soil samples were taken from total nine sites with a representation of seven forest covers

c) Afforestation - selected stands with very short period of afforestation, with the age of forest cover being 10-15 years. The principal overstory species were European Beech (Fagus sylvatica) and Norway Spruce (Picea abies). Other species included European Larch (Larix decidua) and European silver fir (Abies alba). Soil samples were taken from total three sites, representing four forest covers.

d) Pasture - a reference site dominated by herbaceous species such as Achillea millefolium, Myosotis sylvatica and Plantago lanceolata, along with various grass $(\mathrm{Poa})$ species. Soil samples were taken from one site.

e) Cultivated - a reference site representing agricultural use, dominated by maize (Zea mays). Soil samples were taken from two sites.

The second locality (2) was established in the Prague-East district at an average elevation of $390 \mathrm{~m}$. It is situated in the Černokostelecká hills region. Two research sites were established: Dobré pole (2a) and Krymlov (2b).

(2a) Dobré pole site $\left[14^{\circ} 56^{\prime} 9-19^{\prime \prime} \mathrm{E} ; 50^{\circ} 00^{\prime} 50-53^{\prime \prime} \mathrm{N}\right]$ has a mildly warm and slightly dry climate. The mean annual temperature is $8.4^{\circ} \mathrm{C}$ and mean annual precipitation is $591 \mathrm{~mm}$. This area consists of permian-carboniferous rocks and permiancarboniferous sandstone with shale inserts. The soil type was identified as a Haplic Cambisol (FAO, 2006, 2007).

Specification of Dobré Pole site vegetation:

a) Afforestation - the experimental site was established in a stand of 44 year-old Quercus petraea. The forest site was classified as beech acid oak wood. Soil samples were taken from three sites representing one forest cover type.

b) Cultivate - this was a reference site representing agricultural use dominated by maize (Zea mays). Soil samples were taken from three sites.

(2b) Krymlov [ $\left.14^{\circ} 55^{\prime} 27-36^{\prime \prime} \mathrm{E} ; 49^{\circ} 56^{\prime} 40-57^{\prime \prime} \mathrm{N}\right]$. The climatic and geological characteristics are the same as at Dobré pole. The experimental plots were established by planting in 1967. Soil samples indicated that the soil type was a Haplic Stagnosol (classified according to FAO, 2006, 2007).

Specification of Krymlov site vegetation:

a) Forest - the study was conducted in the stands of four tree species on the afforested agricultural lands, in the neighbouring forest stands on continuously forested land (mixed Scots pine - Norway spruce stand) and in the nearby field - arable land. The studied species were Scots pine (Pinus silvestris), Norway Spruce (Picea abies), European white birch (Betula verrucosa) and Douglas-fir (Pseudotsuga menziesii). Soil samples were taken from four sites, each of which represents a forest type.

b) Cultivate - a reference site representing agricultural use, dominated by oilseed rape (Brassica napus subsp.). Soil samples were taken from one site.

c) Pasture - a reference site situated close to the afforested zone.

\section{Soil sampling and analyses}

Soil sampling was conducted during years 2008-2010. Soil samples were taken from all four locations (1a, 1b, 2a, 2b) from the upper soil mineral horizons at a depth of 10-20 cm (Ap - arable, Ad - pasture, Ah - forest horizon) to enable the comparison of soil characteristics under different land management regimes.

In total, 85 disturbed soil samples were taken for the determination of soil chemical characteristics, 183 undisturbed soil samples (using Kopeckýs rings - volume $100 \mathrm{~cm}^{3}$, diameter $5 \mathrm{~cm}$, height $5 \mathrm{~cm}$ ) for measuring soil physical characteristics, 38 samples with undisturbed soil structure for measuring Water stable aggregates (WSA) and MWD, and 38 undisturbed soil samples for measuring $\mathrm{K}_{\text {sat }}$ (saturated hydraulic conductivity). Altogether, 344 soil samples were analysed which in total represented 21 sampling sites, marked as afforest. (12 sites), cultivate (6 sites) and pasture ( 3 sites).

Continuous forest inventory has been conducted on these localities since $c a$. 1960. For the given localities, data from soil sampling in 2008-2010 were chosen. In total, 36 sites representing soils with Old Forest (14 sites) and Forest (22 sites) were chosen. On each of this locality six soil samples were taken. In total, 216 soil samples were selected. All measures were statistically processed in Programme Statistics 9 (StatSoft Inc., 2010). 
Basic analysis was performed on samples of fine particles $(<2 \mathrm{~mm}$ ) (ISO 11464). Determination of TOC (total organically bounded carbon) as $\mathrm{C}_{\text {ox }}$ (total oxidized carbon) (ISO/FDIS 14235), soil organic matter (Nelson, Sommers, 1982), TN (total nitrogen) was conducted according to ČSN ISO 11261, while analysis of potentiometric $\mathrm{pH}(\mathrm{KCl})$ was conducted according to ISO 10390. CEC (cation exchange capacity) and exchangeable cations were measured by AAS-Varian240 (ISO 13536). The fractionation of HL (ratio HK: FK) and the value $\mathrm{Q}_{4 / 6}$ (in pyrophosphate) was done by the method described in Richter, Hlušek (1999). Particle size distribution was determined according to the ISO 11277 and ONORM L 1061, basic physical analyses from Kopecký's rings were done according to ISO 11508, total porosity was expressed from the values of reduced bulk density (OHR) (Blake, Hartge, 1986) and particle density (Danielson, Sutherland, 1986). Saturated hydraulic conductivity $\left(\mathrm{K}_{\text {sat }}\right)$ was determined according to the ČSN 721020 .

The samples for determination of aggregate stability (sample’s weight $3 \mathrm{~kg}$ ) were put into plastic boxes. Samples were dried on the air and distributed on nested sieves (Retch - ISO 3310-1) to particles of 1-2 mm (WSA) and 3-5 mm (MWD) sizes. The method of determination of WSA (water stable aggregates) is described by Kemper and Rosenau (1986).

The index is calculated according to

$$
\mathrm{WSA}_{\mathrm{i}}=\mathrm{Ms}_{\mathrm{i}} /\left(\mathrm{Ms}_{\mathrm{i}}+\mathrm{Mn}_{\mathrm{i}}\right)
$$

where the resulting WSA is statistical average from each partial measurement in this equation, $\mathrm{WSA}_{\mathrm{i}} \mathrm{Ms}_{\mathrm{i}}$ is the weight of water stable phase for given measure and $\mathrm{Mn}_{\mathrm{i}}$ is the weight of water unstable phase for given measure.

The method of determining soil mean weight diameter (MWD) came from Le Bissonais (1996). The test distinguishes three mechanisms of soil aggregates breakdown after their given stress factor. For each sample, three replications of this test were made and the results were averaged. The value MWD is counted according to the following formula:

$$
M W D_{j} \equiv \sum_{i-1}^{n} X_{i} W_{i}
$$

where $\mathrm{X}_{\mathrm{i}}$ is an average aggregate size collected on the sieve $(\mathrm{mm})$ and $\mathrm{W}_{\mathrm{i}}$ is a procentual content of a given particle. The resulting value for MWD is an average of values $\operatorname{MWD}_{j}(j=1,2,3)$ determined for each disruption tests $(j=1$ : fast wetting; $j=2$ : slow wetting; $j=3$ : mechanical disaggregation).

\section{Results and discussion}

The principal aim of the soil survey was to evaluate the effect of afforestation of previously arable land (after 7-10 years) to soil characteristic changes. The influence of forest vegetation was positively related to the formation of soil organic matter and it improved soil structure stability, a relationship which was statistically significant (Fig. 1). These conclusions corresponded with the study of Caravaca et al. (2001).

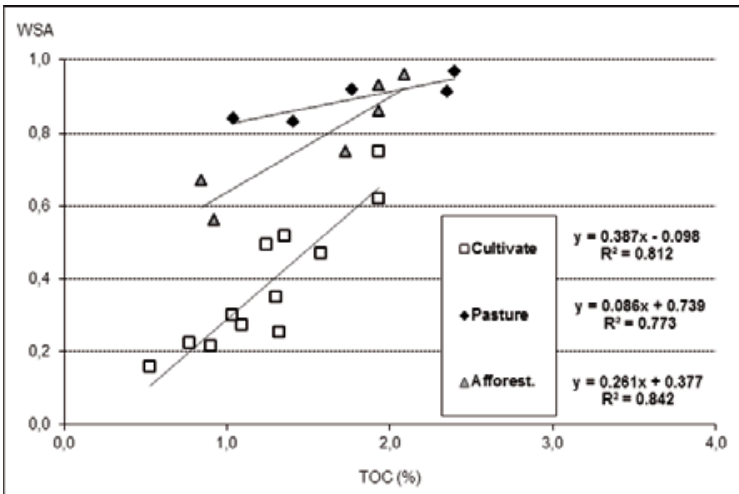

Fig. 1. The effect of afforestation or the presence of grass/herbaceous cover in comparison with arable soil (evaluated from the relation WSA/TOC for upper horizons). 
At research site 1a, we investigated the effect of the presence of important tree species European Beech (Fagus sylvatica) and Norway Spruce (Picea abies) on soil organic matter quality in comparison with pasture. The total humus content (in horizon Ah) didn't decrease after such a short time (7-10 years) after afforestation, but the effect on the quality of soil organic matter is apparent. The evaluation was done on the basis of the ratio HK: FK. The optimal value for this ratio is 1.5 (Richter, Hlušek, 1999); for Fagus sylvatica the value was 1.1 and for the pasture (horizon Ad) the value was 0.2 (selected characteristics for model area 1a are shown in Table 1).

T a b l e 1. Selected soil characteristics for site la (Lomy - Deštné).

\begin{tabular}{|c|c|c|c|c|c|c|c|c|c|}
\hline \multirow{2}{*}{ Study site } & \multirow{2}{*}{ Soils } & \multirow{2}{*}{$\begin{array}{l}\text { Land - use } \\
\text { type }\end{array}$} & \multirow{2}{*}{ Horizon } & TOC & $\mathrm{HS}_{\mathrm{aq}}$ & FA & HA & \multirow[t]{2}{*}{ HA : FA } & \multirow[t]{2}{*}{ Q 4/6 } \\
\hline & & & & $\%$ & $\%$ & $\%$ & $\%$ & & \\
\hline \multirow{3}{*}{ (1a) } & \multirow{3}{*}{$\begin{array}{c}\text { Haplic } \\
\text { Cambisols }\end{array}$} & Spruce & Ah & 3.40 & 2.27 & 1.6 & 1.21 & 1.1 & 5.0 \\
\hline & & Beech & Ah & 3.92 & 2.66 & 1.27 & 1.39 & 1.1 & 5.1 \\
\hline & & Pasture & $\mathrm{Ad}$ & 3.24 & 1.17 & 0.99 & 0.18 & 0.2 & 4.8 \\
\hline
\end{tabular}

Notes: Soils according to FAO $(2006,2007)$ FAO = Food and Agricultural Organization, TOC = total organically bounded carbon, HSaq = humic substances, FA = fulvic acids, HA = humic acids. Upper horizons: Ad - Pasture, $\mathrm{Ah}$ - Afforest.

The hypotheses that bulk density (BD) will decrease and porosity $(\mathrm{P})$ will increase at locations $1 \mathrm{a}$ and $1 \mathrm{~b}$ (Table 2 ) after afforestation was not supported by our results, and contradicts the conclusions from other studies (Reiners et al., 1994; Celik, 2005). On the contrary, it confirms the study of Szujecki (1996), which stated that previously arable horizon characteristics can persist for a long time after afforestation and that analysis of soil characteristics relatively soon after afforestation will not undergo significant changes.

T a b l e 2. Changes in soil physical characteristics by land use type and study site, for sites $1 \mathrm{a}$ and $1 \mathrm{~b}$. Standard deviation is in parentheses.

\begin{tabular}{|c|c|c|c|c|c|c|c|c|c|c|}
\hline \multirow{3}{*}{ 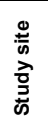 } & \multirow{3}{*}{$\stackrel{n}{\overline{0}}$} & \multirow{3}{*}{ 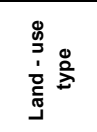 } & \multirow{3}{*}{$\begin{array}{l}\text { ㅁ } \\
\stackrel{N}{2} \\
\text { 오 }\end{array}$} & \multicolumn{4}{|c|}{ Particle size distribution [m m] } & \multirow{3}{*}{$\begin{array}{c}\text { Bulk } \\
\text { density } \\
\mathrm{g} / \mathrm{cm}^{3}\end{array}$} & \multirow{3}{*}{$\begin{array}{l}\text { Particle } \\
\text { density } \\
\text { g/cm }{ }^{3}\end{array}$} & \multirow{3}{*}{$\begin{array}{c}\text { Porosity } \\
\%\end{array}$} \\
\hline & & & & $<0.002$ & $<0.01$ & $0.01-0.05$ & $0.05-2$ & & & \\
\hline & & & & $\%$ & $\%$ & $\%$ & $\%$ & & & \\
\hline \multirow{2}{*}{ (1a) } & \multirow{2}{*}{$\begin{array}{c}\text { Haplic } \\
\text { Cambisols }\end{array}$} & Afforest. & Ah & $10.6(0.6)$ & $28.8(1.9)$ & $38.9(1.7)$ & $32.4(3.5)$ & $1.12(0.01)$ & $2.63(0.06)$ & $57.6(0.5)$ \\
\hline & & Pasture & Ap & $10.5(\mathrm{~N})$ & $29.6(N)$ & $39.2(\mathrm{~N})$ & $31.2(\mathrm{~N})$ & $1.11(\mathrm{~N})$ & $2.71(\mathrm{~N})$ & $59.1(\mathrm{~N})$ \\
\hline \multirow{3}{*}{ (1b) } & \multirow{3}{*}{$\begin{array}{c}\text { Haplic } \\
\text { Cambisols }\end{array}$} & Afforest. & Ah & $8.3(0.9)$ & $22.7(2.0)$ & $24.0(1.1)$ & $53.3(1.8)$ & $1.19(0.02)$ & $2.66(0.03)$ & $55.4(1.3)$ \\
\hline & & Pasture & $\mathrm{Ad}$ & $7.3(\mathrm{~N})$ & $20.0(N)$ & $20.9(\mathrm{~N})$ & $59.0(\mathrm{~N})$ & $1.30(\mathrm{~N})$ & $2.65(\mathrm{~N})$ & $50.9(\mathrm{~N})$ \\
\hline & & Cultivate & $A p$ & $9.0(0.5)$ & $23.4(0.2)$ & $22.6(0.9)$ & $53.8(3.3)$ & $1.22(0.08)$ & $2.64(0.01)$ & $53.8(3.3)$ \\
\hline
\end{tabular}

Notes: Soils according to FAO $(2006,2007)$ FAO = Food and Agricultural Organization, $(\mathrm{N})=$ not significant. Upper horizons: Ap - Cultivate, Ad - Pasture, Ah - Afforest. Standard deviation is in parentheses.

Using detailed hydrophysical soil characteristics evaluation for locality $1 \mathrm{~b}$, we found a relationship between the presence of forest types and the formation of gravitational 
(GP) and semicapillary (SP) pores, or rather the conclusive increase of minimal air capacity and $\mathrm{K}_{\text {sat }}$ value. This positive effect was determined by examining hydraulic conductivity $\mathrm{K}_{\text {sat }}$ measures (Table 3). A similar trend was reported by Jabro (1992).

$\mathrm{T}$ a b l e 3. Selected soil characteristics of study site $1 \mathrm{~b}$. Standard deviation is in parentheses.

\begin{tabular}{|c|c|c|c|c|c|c|c|c|c|}
\hline \multirow{2}{*}{ 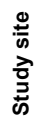 } & \multirow[t]{2}{*}{$\stackrel{n}{\overline{0}}$} & \multirow{2}{*}{ 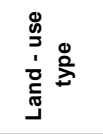 } & \multirow[t]{2}{*}{$\begin{array}{l}\text { 은 } \\
\text { Nㅡㅁ } \\
\text { 오 }\end{array}$} & $\mathbf{P}$ & GP & SP & $\mathrm{CP}$ & $\mathrm{K}_{\text {sat }}$ & \multirow[t]{2}{*}{$\begin{array}{l}\text { WSA } \\
\text { (SD \%) }\end{array}$} \\
\hline & & & & $\%$ & $\%$ & $\%$ & $\%$ & $\mathrm{~ms}^{-1} \times 10^{-6}$ & \\
\hline \multirow{4}{*}{ (1b) } & \multirow{4}{*}{$\begin{array}{c}\text { Haplic } \\
\text { Cambisols }\end{array}$} & Spruce & $\mathrm{Ah}$ & 55.81 & 4.63 & 10.13 & 26.6 & 1.88 & $0.96(0.09)$ \\
\hline & & Beech & $\mathrm{Ah}$ & 56.76 & 6.26 & 12.15 & 25.89 & 1.18 & $0.86(1.59)$ \\
\hline & & Pasture & $\mathrm{Ad}$ & 50.90 & 1.73 & 9.43 & 31.66 & 0.51 & $0.92(0.14)$ \\
\hline & & Cultivate & Ap & 50.45 & 2.32 & 10.27 & 34.44 & 0.62 & $0.62(2.70)$ \\
\hline
\end{tabular}

Notes: Soils according to FAO $(2006,2007)$ FAO = Food and Agricultural Organization, $\mathrm{P}=$ porosity, GP = gravitational pores, $\mathrm{SP}=$ semicapillary pores, $\mathrm{CP}=$ capillary pores, $\mathrm{WSA}=$ Water stable aggregates, Ksat $=$ saturated hydraulic conductivity. Upper horizons: Ap - Cultivate, Ad - Pasture, Ah - Afforest. Standard deviation is in parentheses.

The WSA values are average values from all three measurements. Each forest stand has significant influence on soil organic carbon sequestration. The increase of total organic carbon due to afforestation of agricultural soils is evident from Table 4 . Total organic carbon in forested lands 40-57 years after afforestation was three to four times higher than for agricultural soils or pastures. Similar trends were observed on other research sites within the Czech Republic (Podrázský, Procházka, 2009; Podrázský, Remeš, 2008; Podrázský et al., 2009; Kupka, Podrázský, 2011), where after only a very short period of time (a few decades), the carbon content in mineral soil horizons in afforested lands was a multiple of the value determined for agricultural soils.

$\mathrm{T}$ a b l e 4. Changes in soil chemical characteristics by land use type and study site, for sites $1 \mathrm{a}$ and $1 \mathrm{~b}$. Standard deviation is in parentheses.

\begin{tabular}{|c|c|c|c|c|c|c|c|c|c|c|}
\hline \multirow{3}{*}{ 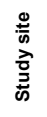 } & \multirow{3}{*}{$\frac{n}{\overline{0}}$} & \multirow{3}{*}{ 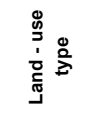 } & \multirow{3}{*}{$\begin{array}{l}\text { 은 } \\
\text { ํㅡㄴ } \\
\text { 오 }\end{array}$} & Hydrolytic & \multicolumn{3}{|c|}{ Exchangeable ions } & \multirow{2}{*}{ CEC } & \multirow{3}{*}{$\mathrm{pH}(\mathrm{KCl})$} & \multirow{2}{*}{ SOM } \\
\hline & & & & acidity & $\mathrm{Ca}^{2+}$ & $\mathrm{Mg}^{2+}$ & $K^{+}$ & & & \\
\hline & & & & $\mathrm{mmol}^{(+)} / 100 \mathrm{~g}$ & \multicolumn{3}{|c|}{$\mathrm{m} \mathrm{mol}^{(+)} / 100 \mathrm{~g}$} & $\mathrm{mmol}^{(+)} / 100 \mathrm{~g}$ & & $\%$ \\
\hline \multirow{4}{*}{ (1a) } & \multirow{4}{*}{$\begin{array}{c}\text { Haplic } \\
\text { Cambisols }\end{array}$} & Old Forest & $\mathrm{Ah}$ & $10.38(6.03)$ & $7.17(4.53)$ & $3.69(3.10)$ & $0.70(0.40)$ & $22.0(6.72)$ & $3.33(0.44)$ & 39.08 (19.19) \\
\hline & & Forest & $\mathrm{Ah}$ & $11.44(4.76)$ & $2.93(2.98)$ & $0.67(0.49)$ & $0.36(0.19)$ & $15.44(3.49)$ & $3.44(0.41)$ & $17.42(7.66)$ \\
\hline & & Afforest. & Ah & $18.78(1.11)$ & $2.89(1.25)$ & $0.83(0.50)$ & $0.27(0.10)$ & $22.76(0.74)$ & $4.04(0.11)$ & $6.31(0.44)$ \\
\hline & & Pasture & $\mathrm{Ad}$ & $16.80(\mathrm{~N})$ & $3.33(\mathrm{~N})$ & $0.72(\mathrm{~N})$ & $0.18(\mathrm{~N})$ & $24.01(\mathrm{~N})$ & $4.14(\mathrm{~N})$ & $5.59(\mathrm{~N})$ \\
\hline \multirow{4}{*}{ (1b) } & \multirow{4}{*}{$\begin{array}{c}\text { Haplic } \\
\text { Cambisols }\end{array}$} & Old Forest & $\mathrm{Ah}$ & $15.94(2.47)$ & $1.07(0.61)$ & $0.27(0.17)$ & $0.25(0.16)$ & $17.58(3.03)$ & $3.00(0.28)$ & $20.04(13.01)$ \\
\hline & & Forest & $\mathrm{Ah}$ & $11.76(3.65)$ & $1.97(1.70)$ & $0.43(0.34)$ & $0, .34(0.16)$ & $14, .51(2.97)$ & $3.28(0.33)$ & $15.99(7.50)$ \\
\hline & & Afforest. & $\mathrm{Ah}$ & $7.00(0.21)$ & $8.18(0.05)$ & $1.46(0.12)$ & $0.37(0.13)$ & $17.00(0.49)$ & $5.19(0.09)$ & $3.42(0.13)$ \\
\hline & & Pasture & $\mathrm{Ad}$ & $9.49(\mathrm{~N})$ & $4.17(\mathrm{~N})$ & $0.43(\mathrm{~N})$ & $0.05(\mathrm{~N})$ & $14.14(\mathrm{~N})$ & $4.32(\mathrm{~N})$ & $3.05(\mathrm{~N})$ \\
\hline
\end{tabular}

Notes: Soils according to FAO $(2006,2007)$ FAO $=$ Food and Agricultural Organization, CEC $=$ cation exchange capacity, $\mathrm{SOM}=$ soil organic matter, $(\mathrm{N})=$ not significant. Upper horizons: Ad - Pasture, Ah - Afforest. Standard deviation is in parentheses. 
At locality 2, the principal aim was to evaluate the effects of each forest species on the soil structure quality 30 to 40 years after afforestation.

On the site 2a (Dobré Pole), we examined the influence of afforestation by specific vegetation types: Quercus petraea L. (1-3) and intensively used agricultural land K(1-3) (Zea mays) on moderately inclined terrain (average slope $3^{\circ}$ ). We found a positive effect of forest cover on $\mathrm{K}_{\text {sat }}$ value, suggesting that soils under forest cover have a significantly greater ability to move precipitation down into the soil profile (Table 5). At the same time, soil structure was stabilized (WSA). The WSA values are a combination of average values derived from three measures. The standard deviation (SD) is expressed in \% in brackets (the accuracy of measure)

T a b l e 5. Selected soil characteristic changes for Dobré Pole site. Standard deviation is in parentheses.

\begin{tabular}{|c|c|c|c|c|c|c|}
\hline \multirow[t]{2}{*}{ 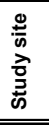 } & \multirow[t]{2}{*}{$\stackrel{n}{\overline{0}}$} & \multirow{2}{*}{ 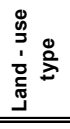 } & \multirow[t]{2}{*}{ 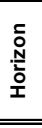 } & $\begin{array}{c}\mathrm{K}_{\mathrm{sat}} \\
m \mathrm{~s}^{-1} \mathrm{x} 10^{-6}\end{array}$ & \multirow[t]{2}{*}{$\begin{array}{c}\text { WSA } \\
\text { (SD \%) }\end{array}$} & \multirow[t]{2}{*}{$\begin{array}{c}\text { MWD (SD) } \\
\mathrm{mm} \\
\end{array}$} \\
\hline & & & & $\mathrm{ms}^{-1} \times 10^{-6}$ & & \\
\hline \multirow{6}{*}{ (2a) } & \multirow{6}{*}{$\begin{array}{c}\text { Haplic } \\
\text { Cambisols }\end{array}$} & L1 & Ah & 27.22 & $0.68(0.58)$ & $2.38(0.52)$ \\
\hline & & K1 & Ap & 2.08 & $0.25(0.84)$ & $1.27(0.37)$ \\
\hline & & L2 & Ah & 177.32 & $0.67(0.13)$ & $2.60(0.63)$ \\
\hline & & K2 & Ap & 14.19 & $0.21(1.05)$ & $1.32(0.16)$ \\
\hline & & L3 & Ah & 105.45 & $0.56(0.67)$ & $2.06(0.35)$ \\
\hline & & K3 & $A p$ & 38.23 & $0.52(4.88)$ & $2.00(0.74)$ \\
\hline
\end{tabular}

Notes: Soils according to FAO $(2006,2007)$ FAO = Food and Agricultural Organization, Ksat - saturated hydraulic conductivity, WSA - water stable aggregates, $\mathrm{MWD}=$ mean weight diameter, $(\mathrm{N})$ = not significant. Upper horizons: Ap - Cultivate, $\mathrm{Ah}$ - Afforest. Standard deviation is in parentheses.

We found no significant influence of afforestation on SOM (Table 6). The most significant criterion for increased particle aggregation under forest cover was the quality of HL (Richter, Hlušek, 1999). Soil organic matter is improved by better soil profile aeration (Table 7). The quality of organic components of forest soils together with the lower $\mathrm{pH}$ level (due to the release of mineral matter) is the cause of stable soil aggregates (Chen et al., 2000).

We concluded that the differences in macronutrient contents can be ascribed to the management impact (reduction of meadows and the fertilization of agricultural lands). The same treatments are probably responsible differences for in soil $\mathrm{pH}$ (Table 6).

The impact of each forest cover (39 years after afforestation) to changes in physical characteristics was also compared on the site $2 \mathrm{~b}$.

Only in this region, which was represented by soil type Haplic Stagnosol, we found a significant impact of each forest cover to the decrease of bulk density and to the reciprocal increase of total porosity. The important soil properties are shown in Table 8 .

We found a strong relationship between the effect of afforestation and the improvement of physical soil characteristics. In total, higher levels of minimum air capacity refer to higher air capacity of these sites. 
T a b l e 6. Changes in soil chemical characteristics by land use type and study site, for sites $2 \mathrm{a}$ and $2 \mathrm{~b}$. Standard deviation is in parentheses.

\begin{tabular}{|c|c|c|c|c|c|c|c|c|c|c|}
\hline \multirow{3}{*}{$\begin{array}{l}\stackrel{0}{0} \\
\frac{ \pm}{n} \\
\frac{\partial}{0} \\
\vec{D}\end{array}$} & \multirow{3}{*}{$\stackrel{\infty}{\overline{0}}$} & \multirow{3}{*}{ 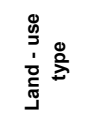 } & \multirow{3}{*}{ 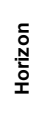 } & Hydrolytic & \multicolumn{3}{|c|}{ Exchangeable ions } & \multirow{2}{*}{ CEC } & \multirow{3}{*}{$\mathrm{pH}(\mathrm{KCl})$} & \multirow{2}{*}{ som } \\
\hline & & & & acidity & $\mathrm{Ca}^{2+}$ & $\mathrm{Mg}^{2+}$ & $\mathrm{K}^{+}$ & & & \\
\hline & & & & $\mathrm{mmol}^{(+)} / 100 \mathrm{~g}$ & \multicolumn{3}{|c|}{$\mathrm{mmol}^{(+)} / 100 \mathrm{~g}$} & $\mathrm{~mm} \mathrm{ol}^{(+)} / 100 \mathrm{~g}$ & & $\%$ \\
\hline \multirow{2}{*}{ (2a) } & \multirow{2}{*}{$\begin{array}{c}\text { Haplic } \\
\text { Cambisols }\end{array}$} & Afforest. & Ah & $6.39(1.39)$ & $1.39(1.00)$ & $0.53(0.24)$ & $0.11(0.05)$ & $8.40(0.21)$ & $3.58(0.17)$ & $1.98(0.31)$ \\
\hline & & Cultivate & Ap & $1.96(0.84)$ & $6.54(0.51)$ & $0.68(0.11)$ & $0.28(0.05)$ & $9.47(0.21)$ & $5.17(0.25)$ & $2.00(0.70)$ \\
\hline \multirow{3}{*}{ (2b) } & \multirow{3}{*}{$\begin{array}{c}\text { Haplic } \\
\text { Stagnosols }\end{array}$} & Afforest. & Ah & $7.72(0.95)$ & $1.84(0.81)$ & $0.69(0.18)$ & $0.13(0.04)$ & $10.37(0.69)$ & $3.58(0.07)$ & $1.86(0.20)$ \\
\hline & & Pasture & $\mathrm{Ad}$ & $0.33(\mathrm{~N})$ & 12.59 & $1.86(\mathrm{~N})$ & $0.59(\mathrm{~N})$ & $15.37(\mathrm{~N})$ & $5.94(\mathrm{~N})$ & $3.70(\mathrm{~N})$ \\
\hline & & Cultivate & $A p$ & $1.54(\mathrm{~N})$ & $6.63(\mathrm{~N})$ & $1.41(\mathrm{~N})$ & $0.25(\mathrm{~N})$ & $9.83(\mathrm{~N})$ & $4.95(\mathrm{~N})$ & $1.80(\mathrm{~N})$ \\
\hline
\end{tabular}

Notes: Soils according to FAO $(2006,2007)$ FAO = Food and Agricultural Organization, CEC = cation exchange capacity, $\mathrm{SOM}=$ soil organic matter, $(\mathrm{N})$ = not significant. Upper horizons: Ap - Cultivate, Ad - Pasture, Ah - Afforest. Standard deviation is in parentheses.

$\mathrm{T}$ a b 1 e 7 . Changes in soil physical characteristics by land use type and study site, for sites $2 \mathrm{a}$ and $2 \mathrm{~b}$. Standard deviation is in parentheses.

\begin{tabular}{|c|c|c|c|c|c|c|c|c|c|c|}
\hline \multirow{3}{*}{ 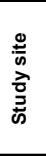 } & \multirow{3}{*}{ 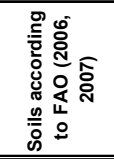 } & \multirow{3}{*}{ 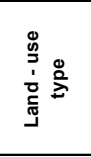 } & \multirow{3}{*}{$\begin{array}{l}\text { 을 } \\
\text { ํㅡㅁ }\end{array}$} & \multicolumn{4}{|c|}{ Particle size distribution $[\mathrm{mm}]$} & \multirow[b]{2}{*}{$\begin{array}{c}\text { Bulk } \\
\text { density }\end{array}$} & \multirow[b]{2}{*}{$\begin{array}{l}\text { Particle } \\
\text { density }\end{array}$} & \multirow[b]{2}{*}{ Porosity } \\
\hline & & & & $<0.002$ & $<0.01$ & $0.01-0.05$ & $0.05-2$ & & & \\
\hline & & & & $(\%)$ & (\%) & (\%) & (\%) & $\left(\mathrm{g} / \mathrm{cm}^{3}\right)$ & $\left(\mathrm{g} / \mathrm{cm}^{3}\right)$ & (\%) \\
\hline \multirow{2}{*}{ (2a) } & \multirow{2}{*}{$\begin{array}{c}\text { Haplic } \\
\text { Cambisols }\end{array}$} & Afforest. & $\overline{A h}$ & $13.8(1.43)$ & $21.3(2.2)$ & $24.1(3.3)$ & $54.6(5.22)$ & $1.43(0.11)$ & $2.65(0.02)$ & 46.0 (3.9) \\
\hline & & Cultivate & Ap & $12.3(1.3)$ & $20.0(3.2)$ & $21.7(0.1)$ & $58.3(3.18)$ & $1.57(0.07)$ & $2.65(0.02)$ & $40.8(2.6)$ \\
\hline \multirow{3}{*}{ (2b) } & \multirow{3}{*}{$\begin{array}{c}\text { Haplic } \\
\text { Stagnosols }\end{array}$} & Afforest. & Ah & $14.7(1.5)$ & $28.4(1.2)$ & $47.4(1.9)$ & $24.3(2.7)$ & $1.35(0.04)$ & $2.63(0.0)$ & $48.6(1.63)$ \\
\hline & & Pasture & $\mathrm{Ad}$ & $10.5(\mathrm{~N})$ & $31.5(\mathrm{~N})$ & $38.8(\mathrm{~N})$ & $29.7(\mathrm{~N})$ & $1.25(\mathrm{~N})$ & $2.60(\mathrm{~N})$ & $51.9(\mathrm{~N})$ \\
\hline & & Cultivate & Ap & $13.9(\mathrm{~N})$ & $30.5(\mathrm{~N})$ & $38.4(\mathrm{~N})$ & $31.1(\mathrm{~N})$ & $1.50(\mathrm{~N})$ & $2.68(\mathrm{~N})$ & $43.9(\mathrm{~N})$ \\
\hline
\end{tabular}

Notes: Soils according to FAO $(2006,2007)$ FAO = Food and Agricultural Organization, $(\mathrm{N})=$ not significant. Upper horizons: Ap - Cultivate, Ad - Pasture, Ah - Afforest. Standard deviation is in parentheses.

T a b l e 8. Selected soil characteristics of the Krymlov site. Standard deviation is in parantheses.

\begin{tabular}{|c|c|c|c|c|c|c|c|c|c|}
\hline \multirow{2}{*}{ 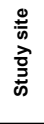 } & \multirow{2}{*}{$\stackrel{\infty}{\overline{0}}$} & \multirow{2}{*}{ 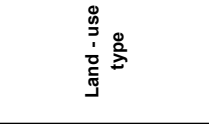 } & \multirow{2}{*}{$\begin{array}{l}\text { 은 } \\
\text { ํㅡㄴ } \\
\text { 오 }\end{array}$} & $\begin{array}{c}\text { Bulk } \\
\text { density }\end{array}$ & Porosity & max. CW & $\min . A C$ & \multirow[t]{2}{*}{ WSA (SD\%) } & \multirow{2}{*}{$\begin{array}{c}\text { MWD (SD) } \\
\mathrm{mm}\end{array}$} \\
\hline & & & & $\mathrm{g} / \mathrm{cm}^{3}$ & $\%$ & $\%$ & $\%$ & & \\
\hline \multirow{6}{*}{ (2b) } & \multirow{6}{*}{$\begin{array}{c}\text { Haplic } \\
\text { Stagnosols }\end{array}$} & Picea abies & Ah & 1.10 & 56.63 & 33.17 & 23.46 & $0.94(1.41)$ & $2.82(0.25)$ \\
\hline & & Pinus silvestris & Ah & 1.14 & 55.16 & 25.80 & 29.36 & $0.81(2.35)$ & $2.76(0.14)$ \\
\hline & & Betula verrucosa & $\mathrm{Ah}$ & 1.15 & 54.70 & 29.98 & 24.72 & $0.68(2.64)$ & $2.58(0.59)$ \\
\hline & & Pseudotsuga menziesii & Ah & 1.23 & 52.16 & 32.75 & 19.41 & $0.48(8.63)$ & $1.85(0.67)$ \\
\hline & & Pasture & Ad & 1.25 & 51.89 & 48.14 & 7.22 & $0.83(0.58)$ & $2.18(0.85)$ \\
\hline & & Cultivate & Ap & 1.46 & 43.89 & 35.66 & 8.23 & $0.25(2.86)$ & $1.44(0.55)$ \\
\hline
\end{tabular}

Notes: Soils according to FAO $(2006,2007)$ FAO = Food and Agricultural Organization, CW = capillary water capacity, min. $\mathrm{AC}=$ minimal air capacity, WSA $=$ water stable aggregates, $\mathrm{MWD}=$ mean weight diameter, $(\mathrm{N})=$ not significant. Upper horizons: Ap - Cultivate, Ad - Pasture, Ah - Afforest. Standard deviation (SD) is in parantheses.

The most appropriate land uses for these soils (in terms of improving and/or maintaining physical characteristics such as porosity and bulk density) for locality 2 are, in order of suitability: Norway Spruce (Picea abies) > Scots pine (Pinus sylvestris) $>$ Silver Birch (Betula 
pendula) $>$ Douglas-fir (Pseudotsuga menziesii) $>$ Pasture $>$ Arable (Cultivated) land (Brassica napus). Figures 2 and 3 show the determination of MWD value. The effect of each forest species on the soil structure stability (WSA) was: Spruce $>$ Pine $=$ Pasture $>$ Birch $>$ Douglasfir $>>$ Arable land.

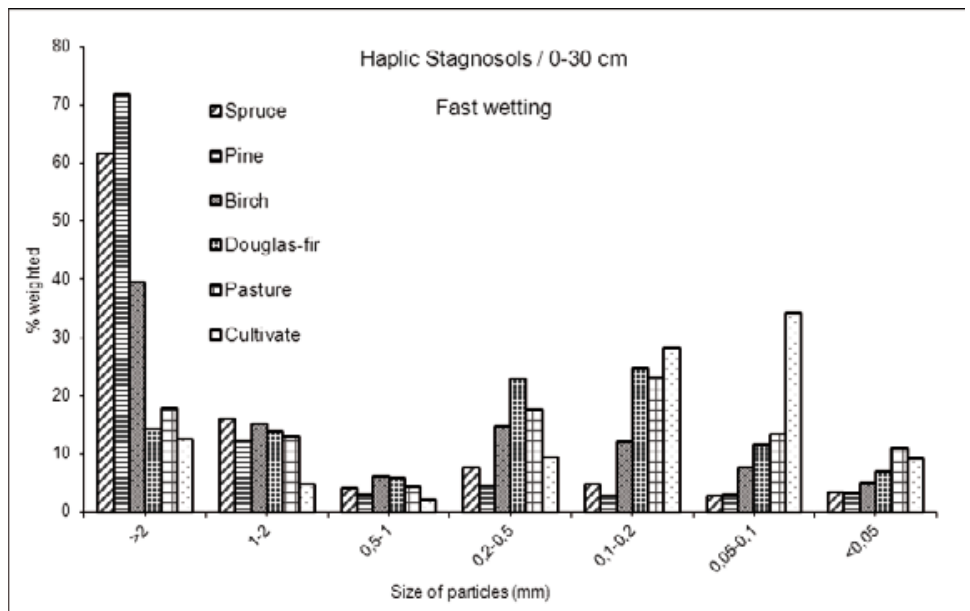

Fig. 2. Particle size distribution (represented by MWD value) of two independent soil sample tests of study site $2 \mathrm{~b}$ - fast wetting test.

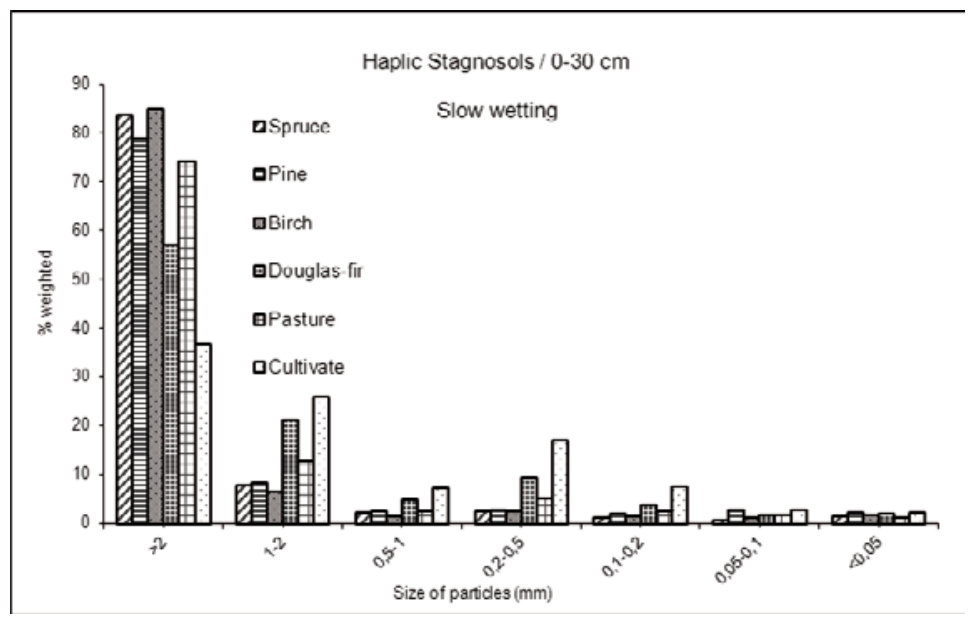

Fig. 3. Particle size distribution (represented by MWD value) of two independent soil sample tests of study site $2 b-$ slow wetting test of defined aggregates of size $3-5 \mathrm{~mm}$.

Figures 2 and 3 show typical product of soil particles disaggregation by forest covers and other land uses. During fast wetting/slow wetting, aggregates are disrupted by slacking/dispersion, typical products of disaggregation are particles of an average size: Spruce 
(2.48/3.09mm); Pine (2.75/2.93mm); Birch (1.76/3.10mm); Douglas-fir (0.92/2.41mm); Pasture $(0.99 / 2.84 \mathrm{~mm})$; Cultivate $(0.66 / 1.84 \mathrm{~mm})$.

\section{Conclusion}

Afforestation of agricultural soil can result in important changes in soil organic matter dynamics compared to agroecosystems. First of all, it starts with the creation and development of humus form, the most easily manipulated part of the soil system (Green et al., 1993).

The development trends and soil status in each phase are locality-dependent, where the combination of macro- and microclimatic, geological and biological factors including production of vegetation litter is involved (Binkley, 1995). Based on our observations, relatively quick restoration of overlying humus dynamics was observed after afforestation by spruce, beech or else woody plant. Relatively quick restoration of the surface humus was also observed by Podrázský and Remeš (2008) in the Orlické mountains. In that study, spruce and beech had been established on former agricultural sites for a period of time representing half their normal rotation age. Over the same period of time, the forest soil accumulated humus representing approximately $50 \%$ of the total amount resident under a permanent forest.

The presence of broad-leaved forest cover had a positive relationship with certain soil chemical characteristics, mainly the calcium content. The restoration of typical forest SOM dynamics is likely expected to be during the first rotation period. Quick initialization of this process was also found by Kacálek et al. $(2007,2009)$.

Other studies conducted in the area of the Forest Establishment at Kostelec nad Černými lesy relatively found a quick revitalization of soil forest dynamics on afforestated agricultural areas (Kupka, Podrázský, 2011; Podrázský et al., 2009), with favourable effect of broad-leaved trees (birch) and an introduced conifer (Douglas-fir). The overlaying humus was regenerated, the values of soil chemical characteristics were closer to the values more frequent for forest soils and nutrient recovery was accelerated. The status of humus forms was changing in qualitative and quantitative ways just as during forest interventions, such as forest regeneration and forest type composition change (e.g. Podrázský, Remeš, 2010). Similar trends were also documented from other regions of the Czech Republic, such as the Orlické mountains (Podrázský, 2008; Podrázský et al., 2010) and Bohemian-Moravian uplands (Podrázský, Procházka, 2009).

On the other hand, the influence of overstory composition and land use to soil physical characteristics and soil structure was not extensively evaluated in this study. In another research study, Podrázský and Remeš (2005) found quite small differences in the values of pedophysical characteristics between forest covers of spruce, Douglas-fir and mixed broad-leaved cover. On the other hand, a clear-cut site displayed a decrease in the capacity of the soil to store water. Forest type was a significant influence. Afforestation was a positive influence on the soil physical characteristics which are important for soil stability maintenance. The influence of forest cover to increasing of soil porosity, by decreasing of reduced bulk density and increasing capillary and gravitational pores (increasing of waterholding capacity and soil air capacity) is crucial. The positive effect on infitration and waterholding soil capacity not only resulted from the presence of a forest overstory, but also from the presence of a permanent grass cover in pastureland. 
Afforestation was also found to be positively related to increases in soil organic matter content in different forms, both stable and unstable, and tendency of considerable SOM accumulation not only in the layer of overlying humus but also in the entire soil profiles of the research sites. Newly established forest covers thus show strong sequestration potential with regard to carbon in its biomass, in humus forms and also in mineral soil horizons.

The main contributor to soil improvement after afforestation is the formation of stable soil aggregates, represented in this study mainly by the values of WSA and MWD. This is typical mainly for spruce and pine cover. The enhancement of a stable soil structure is one of the ways of restoring eroded and otherwise degraded soils. Forest cover based on afforested agricultural soils thus show sharp functional impacts in soil structure formation and regeneration of natural pedogenetical processes in regenerated forest ecosystems.

\section{Acknowledgements}

This study was made possible by the support of research project QH 82090 (20\%) 'Changes of the soil properties due to grassing, afforestation or in the long-term abandoned land regarding to soil, landscape and water conservation in the Czech Republic', research plan MZE0002704902 (30\%) 'The integrated systems of protection, improvement and use of soil, water and landscape in agriculture and rural development' and research project NAZV QI112A172 (50 \%) "Silvicultural approaches applied to use Douglas fir in mixed stands in the Czech Republic". These grants were provided by the Ministry of Agriculture of the Czech Republic.

\section{References}

Binkley, D. (1995). The influence of tree species on forest soils: processes and patterns. In D.J. Mead, I.S. Cornforth (Eds.), Proceedings of the trees and soils workshop (pp. 1-33). Agronomy Society of New Zealand Special Publication, 10, Canterbury, NZ.

Blake, G.R. \& Hartge K.H. (1986). Bulk density. In A. Klute (Ed.), Methods of soil analysis ( pp. 363-375). Part 1. Physical and mineralogical methods. Agronomy Monographs, 9. Madison: ASA-SSA.

Blanco-Canqui, H. \& Lal R. (2004). Mechanisms of carbon sequestration in soil aggregates. Crit. Rev. Plant Sci., 23(6), 481-504. DOI: $10.1080 / 07352680490886842$.

Brown, S. \& Lugo, A.E. (1990). Effects of forest clearing and succession on the carbon and nitrogen content of soils in Puerto Rico and US Virgin Islands. Plant Soil, 124, 53-64. DOI: 10.1007/BF00010931.

Brown, S., Swingl. J.R., Tenison, R.H., Prance, G.T. \& Myers N. (2002). Changes in the use and management of forests for abating carbon emissions: issues and challenges under the Kyoto Protocol. Philos. Trans. R. Soc. Lond. A, 360,1593-1605. DOI: 10.1098/rsta.2002.1021.

Caravaca, F., Lax, A. \& Albaladejo J. (2001). Soil aggregate stability and organic matter in clay and fine silt fractions in urban refuse-amended semiarid soils. Soil Sci. Soc. Am. J., 65, 1235-1238. DOI: 10.2136/sssaj2001.6541235x.

Celik, I. (2005). Land-use effects on organic matter and physical properties of soil in a southern Mediterranean highland of Turkey. Soil Tillage Res., 83, 270-277. DOI: 10.1016/j.still.2004.08.001.

Cerda, A. (2000). Aggregate stability against water forces under different climates on agriculture land and scrubland in southern Bolivia. Soil Tillage Res., 57, 159-166. DOI: 10.1016/S0167-1987(00)00155-0.

Chan, K.Y. \& Heenan D.P. (1998). Effect of lime $\left(\mathrm{CaCO}_{3}\right)$ application on soil structural stability of a red earth. Aust. J. Soil Res., 36(1), 73-86. DOI: 10.1071/S97054.

Chen, C.R., Condron, L.M., Davis, M.R. \& Sherlock R.R. (2000). Effects of afforestation on phosphorus dynamics and biological properties in a New Zealand grassland soil. Plant Soil, 220,151-163. DOI: 10.1023/A:1004712401721.

Danielson, R.E. \& Sutherland P.L. (1986). Porosity. In A. Klute (Ed.) Methods of soil analysis (pp. 443-461). Part 1. Physical and mineralogical methods. Agronomy Monographs, 9. Madison: ASA-SSA.

Del Galdo, I., Six, J., Peressotti, A. \& Cotrufo M.F. (2003). Assessing the impact of land-use change on soil carbon sequestration in agricultural soils by means of organic matter fractionation and stable carbon isotopes. Global Change Biology, 9(8), 1204-1213. DOI: 10.1046/j.1365-2486.2003.00657.x. 
Elliott, E.T. (1986). Physical and mechanical properties of Oxisols. In B.K.G. Theng (Ed.), Soils with variable charge (pp. 303-324). Palmerston North: Offset Publications.

Emadodin, I., Reiss, S. \& Bork R.H. (2009). A study of the relationship between land management and soil aggregate stability (case study near Albersdorf, Northern-Germany). ARPN Journal of Agricultural and Biological Science, $4(4), 48-53$.

Filho, C.C., Lourenço, A., Guimarães, M de F. \& Fonseca I.C.B. (2002). Aggregate stability under different soil management systems in a red latosol in the state of Parana, Brazil. Soil Tillage Res., 65, 45-51. DOI: 10.1016/ S0167-1987(01)00275-6.

Food and Agricultural Organization (FAO) (2006). World Reference Base for Soil Resources 2006, first update 2007. World Soil Resources Reports No. 103. Rome: FAO.

Gartzia-Bengoetxea, N., Gonzalez-Arias, A., Merino, A. \& Martinez de Arano I. (2009). Soil organic matter in soil physical fractions in adjacent semi-natural and cultivated stands in temperate Atlantic forests. Soil Biol. Biochem., 41, 1674-1683. DOI: 10.1016/j.soilbio.2009.05.010.

Green, R.N., Trowbridge, R.L. \& Klinka K. (1993). Towards a taxonomic classification of humus forms. Forest Science, Monograph 29 (Supplement to Nr. 1). Society of American Foresters.

Jabro, J.D. (1992). Estimation of saturated hydraulic conductivity of soils from particle size distribution and bulk density data. Trans. ASAE, 35, 557-560. DOI: 10.13031/2013.28633.

Kacálek, D., Novák, J., Špulák, O., Černohous, V. \& Bartoš J. (2007). Přeměna půdního prostředí zalesněných zemědělských pozemků na půdní prostředí lesního ekosystému - přehled poznatků. Zprávy Lesnického Výzkumu, 52(4), 334-340.

Kacálek, D., Novák, J., Dušek, D., Bartoš, J. \& Černohous V. (2009). How does legacy of agriculture play role in formation of afforested soil properties? J. For. Sci., 55(1), 9-14.

Kaiser, K., Eusterhues, K., Rumpel, C., Guggenberger, G. \& Kogel-Knabner I. (2002). Stabilization of organic matter by soil minerals - investigations of density and particle-size fractions from two acid forest soils. J. Plant Nutr. Soil Sci., 165, 451-459. DOI: 10.1002/1522-2624(200208)165:4<451::AID-JPLN451>3.0.CO;2-B.

Kavvadias, V.A., Alifragis, D., Tsiontsis, A., Brofas, G. \& Stamatelos G. (2001). Litterfall, litter accumulation and litter decomposition rates in four forest ecosystems in northern Greece. For. Ecol. Manag., 144, 113-127. DOI: 10.1016/S0378-1127(00)00365-0.

Kemper, W.D. \& Rosenau R.C. (1986). Aggregate stability and size distribution. In A. Klute (Ed.), Methods of soil analysis (pp. 425-442). Part 1. Physical and mineralogical methods. Agronomy Monographs, 9. Madison: ASA-SSA.

Klute, A. \& Dirksen C. (1986). Hydraulic conductivity and diffusivity. In A. Klute (Ed.), Methods of soil analysis (pp. 687-734). Part 1. Physical and mineralogical methods. Agronomy Monographs, 9. Madison: ASA-SSA.

Kupka, I. \& Podrázský V. (2011). Species composition effects of forest stands on afforested agricultural land on the soil properties. Scientia Agriculturae Bohemica, 42(1), 19-23.

Lal, R. (2002). Soil carbon dynamics in cropland and rangeland. Environ. Pollut., 116, 353-362. DOI: 10.1016/ S0269-7491(01)00211-1.

Lamlom, S.H. \& Savidge R.A. (2003). A reassessment of carbon content in wood: variation within and between 41 North American species. Biomass Bioenerg., 25, 381-388. DOI: 10.1016/S0961-9534(03)00033-3.

Le Bissonais, Y. (1996). Aggregate stability and assessment of crustability and erodibility: I. Theory and methodology. Eur. J. Soil Sci., 47, 425-437. DOI: 10.1111/j.1365-2389.1996.tb01843.x.

Leckie, S.E., Prescott, C.E. \& Graxston S.J. (2004). Forest floor microbial community response to tree species and fertilization of regenerating coniferous forests. Can. J. For. Res., 34, 1426-1435. DOI: 10.1139/x04-028.

Merganičová, K. \& Merganič J. (2010). Coarse woody debris carbon stocks in natural spruce forests of Babia hora. J. For. Sci., 56(9), 397-405.

Marková, I., Pokorný, R. \& Marek M.V. (2011). Transformation of solar radiation in Norway spruce stands into produced biomass - the effect of stand density. J. For. Sci., 57(6), 233-241.

Nambiar, E.K.S. (1996). Sustained productivity of forests is a continuing challenge to soil science. Soil Sci. Soc. Am., 60, 1629-1642.

Nelson, D.W. \& Sommers L.E. (1982). Total carbon, organic carbon, and organic matter. In Page (Ed.), Methods of soil analysis. Part 2. Chemical and microbiological properties (pp. 539-579). Agronomy Monographs, 9. Madison: ASA-SSA.

Podrázský, V. \& Remeš J. (2005). Retenční schopnost svrchní vrstvy půd lesních porostů s různým druhovým složením (in Czech). Zprávy Lesnického Výzkumu, 50(1), 46-48. 
Podrázský, V. (2008). Tvorba povrchového humusu při zalesňování zemědělských ploch a po buldozerové př́pravě v Krušných horách (in Czech). Zprávy Lesnického Výzkumu, 53(4), 258-263.

Podrázský, V. \& Remeš J. (2008). Rychlost obnovy charakteru lesních půd na zalesněných lokalitách Orlických hor. Zprávy Lesnického Výzkumu, 53(2), 89-93.

Podrázský, V. \& Procházka J. (2009). Effects of the reforestation of agricultural lands on the humus form development in the midle altitudes. Scientia Agriculturae Bohemica, 40(1), 41-46.

Podrázský, V., Remeš, J., Hart, V. \& Moser W.K. (2009). Production and humus form development in forest stands established on agricultural lands - Kostelec nad Černými lesy region. J. For. Sci., 55(7), 299-305.

Podrázský, V., Kapička, A. \& Kouba M. (2010). Restoration of forest soils after bulldozer site preparation in the Ore mountains over 20 years development. Ekológia (Bratislava), 29(3), 281-289. DOI: 10.4149/ekol_2010_03_281.

Podrázský, V. \& Remeš J. (2010). Vliv druhové skladby lesních porostů na stav humusových forem na území ŠLP v Kostelci nad Černými lesy. Zprávy Lesnického Výzkumu, 55(2), 71-77.

Reiners, W.A., Bouwman, A.F., Parsons, W.F.J. \& Keller M. (1994). Tropical rain forest conversion to pasture: Changes in vegetation and soil properties. Ecol. Appl., 4(2), 363-377. DOI: 10.2307/1941940.

Richter, R. \& Hlušek J. (1999). Výživa a hnojení rostliny - obecná část . Brno: MZLU.

Sariyildiz, T., Anderson, J.M. \& Kucuk M. (2005). Effects of tree species and topography on soil chemistry, litter quality and decomposition in Northeast Turkey. Soil Biol. Bioch., 37, 1695-1706. DOI: 10.1016/j.soilbio.2005.02.004.

Sefidi, K. \& Mohadjer M.R. (2010). Characteristics of coarse woody debris in successional stages of natural beech (Fagus orientalis) forests of Northern Iran. J. For. Sci., 56(1), 7-17.

Seely, B., Welham, C. \& Kimmins H. (2002). Carbon sequestration in a boreal forest ecosystem: results from the ecosystem simulation model. For. Ecol. Manag., 169(1-2), 123-135. DOI: 10.1016/S0378-1127(02)00303-1.

Six, J., Elliott, E. \& Paustian K. (2000). Soil macroaggregate turnover and microaggregate formation: A mechanisms for carbon sequestration under no-tillage agriculture. Soil Biol. Biochem., 32, 2099-2103. DOI: 10.1016/S00380717(00)00179-6.

StatSoft Inc (2010). STATISTICA (data analysis software system), version 9.1. www.statsoft.com.

Szujecki, A. (1996). Ekologiczne aspekty odtwarzania lasu na glebach porolnych. Prace IBL, ser. B, 27, 47-55.

Tisdall, J.M. \& Oades J.M. (1982). Organic matter and water-stable aggregates in soils. J. Soil Sci., 33(2), 141-163.

Vesterdal, L., Ritter, E. \& Gundersen P. (2002). Change in soil organic carbon following afforestation of former arable land. For. Ecol. Manag., 169(1-2), 137-147. DOI: 10.1016/S0378-1127(02)00304-3.

Wie, C., Gao, M., Shao, J., Wie, D. \& Pan G. (2006). Soil aggregate and its response to land management practices. China Particuology, 4(5), 211-219. DOI: 10.1016/S1672-2515(07)60263-2.

\section{Soil analysis references:}

Czech Standard (ČSN) ISO 10390: Soil quality. Determination of pH. 1996. Czech Standard Institute. 1996, Prague.

ISO 13536: Soil quality - Determination of the potential cation exchange capacity and exchangeable cations using barium chloride solution buffered at $\mathrm{pH}=8,1$. 1995. ISO, Geneve.

ISO 11261: 1995: Soil quality - Determination of total nitrogen - Modified Kjeldahl method. 1995.

ISO 11508: Soil quality - Determination of particle density. 1998. ISO, Geneve

ISO 14235, ONORM L 1081: Soil quality - Determination of organic carbon by sulfochromic oxidation. 1998. ISO, Geneve.

ISO 3310-1:2000: Test sieves - Technical requirements and testing - Part 1: Test sieves of metal wire cloth. 2000.

ISO 11277: 2009. Soil quality - Determination of particle size distribution in mineral soil material - Method by sieving and sedimentation. 2009.

ONORM L 1061: ÖNORM L 1061-1. (2002): Physikalische Bodenuntersuchungen - Bestimmung der Korngrößenverteilung des Mineralbodens; Teil 1: Grobboden. Wien: Österreichisches Normungsinstitut.

ÖNORM L 1061-2. (2002): Physikalische Bodenuntersuchungen - Bestimmung der Korngrößenverteilung des Mineralbodens; Teil 2: Feinboden. Wien: Österreichisches Normungsinstitut.

Czech Standard (ČSN) 72 1020, replaced by ISO/TS 17892-11:2004: Geotechnical investigation and testing - Laboratory testing of soil - Part 11: Determination of permeability by constant and falling head

ISO 11464:_Soil quality - Pretreatment of samples for physico-chemical analysis 